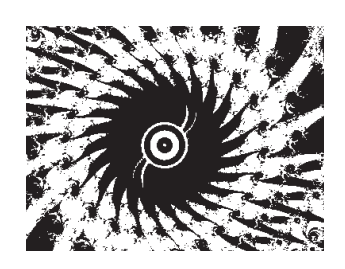

\title{
TEORIJSKO UTEMELJENJE RAČUNALNIH SUSTAVA ZA PROFESIONALNO SAVJETOVANJE
}

Toni BABAROVIĆ, Iva ŠVERKO

Institut društvenih znanosti Ivo Pilar, Zagreb

UDK: 37-048.4:004.738.5

Izvorni znanstveni rad

Primljeno: 14. 7. 2012.

U radu se razmatraju suvremeni računalni sustavi za profesionalno savjetovanje, njihovo teorijsko utemelienje i glavne karakteristike. Najprije je opisan razvoj sustava za računalno potpomognuto profesionalno savjetovanje, s naglaskom na današnju generaciju internetskih savjetodavnih sustava. Zatim je objašnjen pojam kongruencije ili sklada pojedinca i radne okoline, prema kojem će pojedinci koji su odabrali karijeru u skladu sa svojim osobinama biti zadovoljniji poslom te uspješniji $u$ radu. lako je koncept kongruencije temelj računalnih sustava za profesionalno savjetovanje i diferencijalističkih teorija izbora zanimanja, rezultati najvažnijih metaanaliza sustavno upućuju na niske povezanosti kongruencije i zadovolistva poslom. Navode se objašnjenja za takve nalaze, a kao moguće rješenje ističe se pristup kongruenciji preko aspekata posla i objašnjavaju se njegove specifičnosti. Na kraju se opisuje sedam najpoznatijih sustava za profesionalno savjetovanje preko interneta: Discover, SIGI, O*Net, Making Better Career Decisions, Vodič kroz zanimanja, Izbor zanimanja i Slikovno-opisni upitnik interesa.

Ključne riječi: računalno potpomognuto profesionalno savjetovanje, diferencijalističke teorije izbora zanimanja, kongruencija, aspekti posla, internet

Toni Babarović, Institut društvenih znanosti Ivo Pilar, Marulićev trg 19/1, p. p. 277, 10001 Zagreb, Hrvatska. E-mail: Toni.Babarovic@pilar.hr 


\section{RAZVOJ SUSTAVA ZA RAČUNALNO POTPOMOGNUTO PROFESIONALNO SAVJETOVANJE}

Računalno potpomognuto profesionalno savjetovanje jest proces profesionalnog usmjeravanja, informiranja i savjetovanja uz pomoć računala. U literaturi se najčešće govori o sustavima koji računalno potpomažu profesionalno savjetovanje, odnosno o Computer-Assisted Career Guidance Systems, uza što se veže i izvedeni akronim CACGS. Sampson (1994., 1997.) navodi da su to računalni sustavi osmišljeni tako da poboljšavaju samoprimjenu upitnika, generiranje profesionalnih i obrazovnih opcija te baratanje informacijama o zanimanjima, obrazovnim programima i perspektivama zapošljavanja. Nešto drugačiju definiciju računalnih sustava za profesionalno savjetovanje daje Gati (1994., 51), koji ih vidi kao "implementaciju akumuliranog znanja o zanimanjima i profesionalnom savjetovanju koja olakšava kvalitetnije donošenje odluka o razvoju karijere". Carson (2002.) ih, u svojem rječniku psihologije rada, određuje kao računalne sustave kojima su ciljevi uparivanje pojedinaca i zanimanja te opća podrška usmjeravanju, savjetovanju i profesionalnom razvoju pojedinca. Takvi sustavi olakšavaju donošenje profesionalnih odluka i istraživanje profesionalnih opcija, a istodobno su i izvor kvalitetnih informacija o osobinama zanimanja i svijeta rada. Svaki takav računalni sustav trebao bi pomoći klijentima da razviju vještine donošenja profesionalnih odluka, da upoznaju svoje vrijednosti, interese i sposobnosti važne za profesionalni odabir, informiraju se i bolje razumiju svijet rada, a sve to zato da bi donijeli zadovoljavajuće i realne profesionalne odluke (Iaccarino, 2001.).

Računalni sustavi za profesionalno usmjeravanje i savjetovanje mogu biti informacijski sustavi, koji klijentu olakšavaju proces odabira odgovarajućega zanimanja, pružajući mu informacije o zanimanjima, obrazovnim profilima i obrazovnim institucijama, ili savjetodavni, koji klijentu daju povratnu informaciju o za njega najpovoljnijem zanimanju ili području djelatnosti, ili pak o njegovim osobinama koje su važne za izbor zanimanja, poput interesa ili vrijednosti. Danas, većina poznatih, teorijski utemeljenih i široko primijenjenih sustava za računalno potpomognuto profesionalno savjetovanje ima zastupljene obje funkcije. Računalni sustavi razvijali su se od polovice 20. stoljeća do danas, a njihov se razvoj može konceptualizirati kroz pet generacija (Rayman, 1990.; Katz, 1993.; Carson i Carthwright, 1997.; Reile i Harris-Bowlsbey, 2000.; Carson, 2000.). Glavno obilježje današnje, pete, generacije računalnih sustava za profesionalno savjetovanje jest njihova dostupnost na internetu. Razvoj interneta imao je izvanredan utjecaj na profesionalno savjetovanje, pokrenuvši ekspanziju 
on-line primjene psihologijskih testova u domeni profesionalne orijentacije. S daljnjim napretkom tehnologije očekuje se i razvoj novih instrumenata i pristupa, porast broja korisnika, kao i porast kvalitete i tehničkih mogućnosti računalnih savjetodavnih sustava (Oliver i Whiston, 2000.).

\section{KONGRUENCIJA: TEORIJSKO UTEMELJENJE RAČUNALNO POTPOMOGNUTOGA PROFESIONALNOG SAVJETOVANJA}

Svi sadašnji računalni sustavi za profesionalno usmjeravanje i savjetovanje prihvaćaju paradigmu profesionalnoga savjetovanja, koja se zasniva na kongruenciji osobina korisnika i osobina zanimanja, odnosno djeluju unutar općeprihvaćenoga savjetodavnog modela sklada pojedinca i okoline (P-O sklad). Različiti sustavi različito definiraju i operacionaliziraju varijable kojima ostvaruju kongruenciju. To mogu biti interesi, radne vrijednosti ili aspekti posla, no cilj je uvijek isti: sustavi pokušavaju na osnovi osobina, vještina i preferencija klijenata dati savjet o zanimanjima koja im najbolje odgovaraju. Pretpostavka je da će u takvom zanimanju budući zaposlenici biti zadovoljni, postizati bolje radne rezultate, doživljavati nižu razinu stresa i slično. Uglavnom, odabir zanimanja kongruentnog osobinama i preferencijama klijenta imat će kao posljedicu dobrobit za pojedinca i korist za radnu organizaciju.

U psihologiju izbora zanimanja ideju o slaganju osobina pojedinca i okoline uveo je još Frank Parsons (1909.) na početku 20. stoljeća. Parsons (1909., 5) navodi: "Pri mudrom izboru zanimanja postoje tri važna faktora: 1) jasno razumijevanje sebe, svojih sklonosti, vještina, interesa, ambicija, sposobnosti, ograničenja te razumijevanje njihovih uzroka; 2) znanje o zahtjevima, uvjetima, prednostima i nedostacima, nagradama, mogućnostima i perspektivama u različitim područjima rada; te 3) ispravno zaključivanje o odnosima te dvije skupine činjenica." Parsons je vjerovao da bi pojedinci koji se aktivno posvete izboru svojega zanimanja i dobro razmotre sve navedene faktore trebali ostvariti kvalitetan izbor zanimanja, koji bi u konačnici trebao dovesti do većega zadovoljstva poslom, manjih troškova za poslodavca i veće efikasnosti.

Sredinom 1950-ih godina razvile su se dvije najpopularnije diferencijalne teorije izbora zanimanja, bazirane na usklađivanju osobina pojedinca i radne okoline: Hollandova teorija izbora zanimanja (Holland, 1959.) i teorija prilagodbe radu (Dawis i sur., 1964.). Obje su se teorije godinama razvijale i dopunjavale (Holland, 1976., 1997.; Dawis i sur., 1968.; Dawis i Lofquist, 1984.; Dawis, 1996.), a Hollandova je zbog svoje jednostavnosti i primjenjivosti postala najpopularnija teorija izbora zanimanja.

Holland (1997.) pretpostavlja da postoji šest tipova ličnosti i šest korespondentnih tipova radnih okolina: realistički, 
DRUŠ. ISTRAŽ. ZAGREB GOD. 21 (2012), BR. $4(118)$

STR. 863-883

BABAROVIĆ, T., ŠVERKO, I.: TEORIJSKOO.. istraživački, umjetnički, socijalni, poduzetnički i konvencionalni tip. Najveća kongruencija ostvaruje se onda kada se osoba nalazi u istovjetnoj radnoj okolini, a ona dovodi do visokoga zadovoljstva poslom i dobrih profesionalnih dostignuća (Holland, 1997.). Tipovi ličnosti operacionalizirani su upitnicima profesionalnih interesa; najčešće na temelju upitnika Vocational Preference Inventory VPI (Holland, 1985.) ili Self-directed Search SDS (Holland, 1994.), od kojih je potonji kod nas preveden i validiran kao Upitnik za samoprocjenu profesionalnih interesa USPI (I. Šverko i Babarović, 2006.). Zanimanja su pak definirana pripadajućim RIASEC kodovima na temelju procjena stručnjaka (Environment Assessment Technique EAT) ili na temelju tipičnih osobina pojedinaca zaposlenih u pojedinim zanimanjima, a opsežan popis zanimanja i pripadajućih kodova nalazi se $\mathrm{u}$ Dictionary of Holland Occupational Codes (Gottfredson i Holland, 1989.). Na taj se način svaki pojedinac i svako zanimanje mogu opisati RIASEC profilom. Sličnost između osobina pojedinca i karakteristika okoline - kongruencija - najčešće se izračunava preko troslova, odnosno tri najizraženija RIASEC tipa, iako ima pristupa koji se oslanjaju samo na slaganje dominantnih tipova, ali i onih koji uzimaju u obzir svih 6 RIASEC tipova (Tinsley, 2000.; Spokane i sur., 2000.). Brojčani indeksi za izračunavanje kongruencije vrlo su raznoliki i u dosadašnjim istraživanjima (npr. Assouline i Meir, 1987.; Tranberg i sur., 1993.) pojavljuje ih se više od desetak.

Teorija prilagodbe radu (Dawis i sur., 1968.; Dawis i Lofquist, 1984.; Dawis, 1996.) sklad pojedinca i okoline definira na temelju dvaju elemenata. Prvi je odnos između čovjekovih potreba (eng. needs) i potkrepljenja što ih pruža radna okolina (eng. reinforcers). Radnik ima specifične radne potrebe za potkrepljenjima, poput plaće, ugodnih suradnika, dobrih radnih uvjeta ili zanimljiva posla, a radno mjesto koje mu to omogućuje postaje izvor potkrepljenja. Drugi element P-O sklada $\mathrm{u}$ teoriji prilagodbe radu zasniva se na korespondenciji zahtjeva posla i radnih vještina radnika. Svaka radna okolina, odnosno svako zanimanje, ima svoje zahtjeve kojima radnik treba moći udovoljiti svojim vještinama, znanjima i sposobnostima. Slaganje potreba i potkrepljenja trebalo bi rezultirati zadovoljstvom poslom, a slaganje zahtjeva posla i vještina radnika kvalitetom rada, odnosno produktivnošću.

U okviru teorije prilagodbe radu razvijeni su brojni instrumenti. Tako su potrebe (zapravo vrijednosti) radnika operacionalizirane upitnikom radnih vrijednosti Minnesota Importance Questionnaire (MIQ), dok su potkrepljenja koja pruža pojedina radna okolina operacionalizirana korespondentnim upitnikom Minnesota Job Description Questionnaire (MJDQ). Oba upitnika sastoje se od 20 istih aspekata rada za koje pojedinci 
DRUŠ. ISTRAŽ. ZAGREB GOD. 21 (2012), BR. 4 (118),

STR. 863-883

BABAROVIĆ, T. ŠVERKO, I.: TEORIJSKO. procjenjuju njihovu važnost (MIQ), dok se za okoline procjenjuje njihova prisutnost (MJDQ). Slaganje između profila pojedinca i profila radne okoline na tih 20 vrijednosti procjenjuje se na temelju korelacija ili euklidskih distanci, pri čemu veće slaganje upućuje na bolju usklađenost pojedinaca i radne okoline. Na sličan su način vještine radnika i zahtjevi posla procijenjeni korespondentnim mjerama: vještine i sposobnosti radnika procijenjene su testom General Aptitude Test Battery (GATB), dok su zahtjevi zanimanja procijenjeni na korespondentnoj skali Occupational Aptitude Pattern (OAP).

Sklad osobina pojedinca i radne okoline centralni je konstrukt i u drugim modelima psihologije rada, obrazovanja, savjetovanja ili menadžmenta (Tinsley, 2000.). Svi modeli P-O sklada imaju strukturnu sličnost, a razlikuju se u prvom redu u načinu kako određuju preferencije i sposobnosti pojedinca, odnosno kako definiraju obilježja i zahtjeve radne okoline. Ipak, postavlja se pitanje u kojoj su mjeri kongruencija (Holland), korespondencija (TWA), odnosno P-O sklad, povezani s pozitivnim ishodima rada.

\section{DOSEZI KONGRUENCIJE POJEDINCA I OKOLINE U OBJAŠNJENJU RADNOGA PONAŠANJA}

U U literaturi ima mnogih istraživanja kojima se ispituje povezanost sklada osobina pojedinca i okoline s drugim vanjskim varijablama. Većina ih se zasniva na Hollandovoj teoriji, odnosno kongruenciji RIASEC tipova interesa i radnih okolina te odnosa razine kongruencije i zadovoljstva poslom. Nekoliko opsežnih metaanaliza povezanosti kongruencije utemeljene u Hollandovoj teoriji i zadovoljstva poslom pokazale su relativno skromne odnose tih dviju varijabli - prosječne korelacije kretale su se u rasponu od 0,10 do 0,25 (Assouline i Meir, 1987.; Spokane i sur., 2000.; Tranberg i sur., 1993.; Tsabari i sur., 2005.). Ovisno o moderacijskim efektima (npr. vrste indeksa kongruencije, vrste mjera interesa, radne okoline ili pak zadovoljstva poslom), povezanost kongruencije i zadovoljstva poslom varira od nulte povezanosti, pa do, u rijetkim slučajevima, korelacije od 0,40 (Spokane i sur., 2000.; Tranberg i sur., 1993.; Tsabari i sur., 2005.). Na temelju rezultata mnogih istraživanja čini se da korelacija kongruencije i zadovoljstva poslom rijetko prelazi čarobnu granicu od 0,30 (Spokane, 1985.), odnosno da kongruencija može u najboljem slučaju protumačiti tek oko $10 \%$ varijabiliteta zadovoljstva poslom.

Istraživanja povezanosti korespondencije i zadovoljstva poslom unutar teorije prilagodbe radu nešto su rjeđa, ali pokazuju slične rezultate. Korelacije između različitih koeficijenata korespondencije baziranih na korelacijama i euklidskim distancama i zadovoljstva poslom generalno su niske. Mjere ko- 
DRUŠ. ISTRAŽ. ZAGREB GOD. 21 (2012), BR. $4(118)$

STR. 863-883

BABAROVIĆ, T., ŠVERKO, I.: TEORIJSKO respondencije dobivene preko korelacija pokazuju da je prosječna povezanost zadovoljstva i kongruencije oko 0,20 , dok je u slučaju primjene euklidskih distanci ta povezanost još i niža (Rounds i sur., 1987.).

Ovako skromne povezanosti mjera P-O sklada i zadovoljstva poslom odudaraju od teorijskih očekivanja. Bez obzira na to rabe li se interesi (Holland) ili vrijednosti (TWA) kao mjere osobina pojedinca, povezanost kongruencije, odnosno korespondencije, i zadovoljstva poslom uglavnom je niska. Razlozi niskih korelacija mogu biti mnogi. Neki od njih vezani su uz teorijske konceptualizacije, specifičnosti upotrijebljenih mjera profesionalnih preferencija, radnih okolina ili zadovoljstva poslom, ili pak leže u manjkavostima izračunanih indeksa P-O sklada.

Jedan od problema jest restrikcija varijabiliteta zadovoljstva poslom i P-O sklada (Tinsley, 2000.). Većina ljudi koja dulje radi $\mathrm{u}$ istom zanimanju zadovoljna je svojim poslom, a $\mathrm{i}$ istraživanja se često provode unutar samo jedne radne organizacije u kojoj su karakteristike zajedničke za sve ispitanike. Nadalje, najčešće se primjenjuje metoda prisutnih radnika, odnosno ispituju se samo oni koji rade na konkretnom radnom mjestu, dok su oni koji su odustali ili su dobili otkaz izuzeti iz takvih nacrta, što povećava P-O sklad i smanjuje njegov varijabilitet (Chartrand i Walsh, 1999.; Tracey i sur., 2000.; Rounds i sur., 1987.).

Nadalje, trenutačni okolinski faktori mogu biti jednako dobar prediktor zadovoljstva poslom kao i sklad pojedinca i radne okoline (Tinsley, 2000.). Drugim riječima, svi će radnici, bez obzira na usklađenost svojih preferencija i radnoga mjesta, biti zadovoljni poslom ako rade $\mathrm{u}$ tvrtki koja im daje visoke plaće, mnoge povlastice, dobre radne uvjete ili ugodne suradnike. Problem su i jednodimenzionalne mjere općega zadovoljstva poslom. Dawis (1990.) i Prediger (2000.) upozoravaju da se zadovoljstvo poslom može podijeliti na intrinzično zadovoljstvo (zadovoljstvo sadržajem posla i radnim zadacima) i ekstrinzično zadovoljstvo (zadovoljstvo uvjetima rada ili plaćom), što je maskirano primjenom jednodimenzionalnih mjera. Intrinzična komponenta zadovoljstva poslom trebala bi biti izravnije povezana s mjerama P-O sklada, pogotovo ako se one zasnivaju na mjerama interesa. U skladu s tim Fritzsche i Parrish (2005.) navode da bi pri mjerenju zadovoljstva poslom trebalo primijeniti facetni pristup, koji bi pokazao veću povezanost kongruencije i onih faceta zadovoljstva poslom koje se odnose na sam sadržaj rada negoli npr. na plaću ili ugodne suradnike. I Tinsley (2000.) smatra kako facetni pristup omogućuje uvid u veze između pojedinih aspekata P-O sklada i pojedinih faceta zadovoljstva poslom te povećava snagu kongruencije za objašnjavanje radnoga ponašanja. 
DRUŠ. ISTRAŽ. ZAGREB GOD. 21 (2012), BR. 4 (118),

STR. 863-883

BABAROVIĆ, T. ŠVERKO, I.: TEORIJSKO.
Naposljetku, povezanost kongruencije i zadovoljstva poslom bila bi veća kad bi se uzimale istovjetne mjere osobina pojedinca, osobine radnih okolina te aspekti zadovoljstva (Tinsley, 2000.). Konkretno, mjera P-O sklada za, primjerice, razinu odgovornosti mogla bi se odrediti kao razlika između željene razine odgovornosti (preferencije) i stvarne razine odgovornosti koju pojedinac ima na svojem radnom mjestu (karakteristike okoline), a tako izvedena varijabla kongruencije trebala bi optimalno predviđati upravo zadovoljstvo aktualnom razinom odgovornosti. Takvo izravno povezivanje pojedinih aspekata P-O sklada i korespondentnih faceta zadovoljstva poslom moglo bi postići znatno veće koeficijente korelacije od dosad primijenjenih općih mjera (Tinsley, 2000.). Na tragu ovoga razmišljanja Gati (1998.) predlaže da se faktori koji se razmatraju prilikom utvrđivanja P-O sklada prošire na sve varijable koje se pojedincu čine relevantnima prilikom odabira zanimanja. On predlaže da se, osim interesa i vrijednosti, u mjere kongruencije uključe i dodatne varijable, poput radnih uvjeta, duljine školovanja za pojedino zanimanje ili količine putovanja koje pojedini posao zahtijeva. Gati smatra kako se takvim aspektima posla realističnije i mnogo izravnije mogu opisati osobine pojedinoga posla, odnosno radne preferencije pojedinca, te da bi se takvim pristupom trebala postići bolja mjera kongruencije, koja bi mogla imati veću prediktivnu valjanost u prognozi radnoga ponašanja.

\section{ASPEKTI POSLA KAO MJERA KONGRUENCIJE I NJIHOV DOPRINOS RAČUNALNO POTPOMOGNUTOM SAVJETOVANJU}

Aspekti posla odnose se na sve relevantne osobine pojedinca i zanimanja koje mogu biti važne u procesu donošenja profesionalnih odluka (Gati, 1998.; Gati i Asher, 2001.). To mogu biti razni aspekti, poput zarade, duljine školovanja, prestiža koji donosi posao, rada na otvorenom ili zatvorenom ili pak spretnosti ruku i prstiju. Dakle, aspekti posla predstavljaju razne kategorije varijabli koje uključuju interese, potrebe, radne vrijednosti, sposobnosti, radne uloge ili stilove radnoga ponašanja. U definiranju aspekata posla Gati se oslanja na Pryora (1982.) i njegovu integraciju vrijednosti, radnih preferencija, potreba, radne etike i orijentacije prema radu u jedinstven set varijabli predstavljen upitnikom Work Aspects Preference Scale (WAPS). Gati (1998.) naglašava da upotreba isključivih kategorija, poput interesa, potreba ili vrijednosti, ograničuje upotrebu svih relevantnih obilježja u procesu uparivanja osobina pojedinca i radne okoline. Tako se u Hollandovoj tipologiji rabi samo šest tipova interesa, unutar teorije prilagodbe radu samo 20 potreba, a čak i integrirana mjera, poput Pryorova WAPS-a, uzima samo 13 aspekata. Po Gatijevu mišljenju, as- 
DRUŠ. ISTRAŽ. ZAGREB GOD. 21 (2012), BR. 4 (118),

STR. 863-883

BABAROVIĆ, T., ŠVERKO, I.: TEORIJSKOO.. pekti posla nude mogućnost primjene znatno više mjera za uparivanje osobina pojedinca i posla, odnosno upotrebu svih relevantnih varijabli bez obzira na teorijske okvire iz kojih proizlaze, što bi moglo pridonijeti boljem i vjernijem opisu osobina pojedinca i radne okoline, odnosno formiranju bolje mjere kongruencije.

Gati (1998.) navodi da upotreba aspekata posla u usporedbi s upotrebom profesionalnih interesa ima jasne prednosti. Aspekti posla pružaju mogućnost finije i osjetlivije upotrebe interesa u procesu odabira zanimanja, za razliku od širokih tipova interesa (poput Hollandovih), koji ne omogućuju upoznavanje specifičnih razlika $u$ interesima pojedinaca ili $\mathrm{u}$ osobinama radnih okolina istoga dominantnog tipa. Nadalje, aspekti posla uključuju mnoge mjere nezavisne od mjera interesa, čime se kvalitetnije mogu opisati profesionalne preferencije ili osobine zanimanja (Gati i sur., 1996.). Na primjer, godine potrebnog obrazovanja, visina zarade, mogućnost napredovanja samo su neki od aspekata koji se mogu značajno razlikovati među zanimanjima unutar jednoga Hollandovog tipa radnih okolina. Danas gotovo svi noviji teorijski koncepti zasnovani na interesima uključuju i druge varijable kako bi poboljšali opis preferencija ispitanika i radnih okolina, a time i mjeru kongruencije. Tako Tracey (2002.) u svojem sfernom modelu interesa uvodi dimenziju prestiža, koja je tradicionalno bila vezana uz domenu vrijednosti, dok novije inačice Strongova upitnika interesa (Strong Interest Inventory SII; Harmon i sur., 1994.) uključuju i "Skale osobnog stila", odnosno preferencije za razne stilove rada, učenja, vođenja, preuzimanja rizika i rada u grupi. Neki od računalnih sustava koji su svoj profesionalni savjet nekada temeljili samo na interesima danas kombiniraju interese i radne vrijednosti u profesionalnom savjetovanju (primjerice Discover; Prediger i Staples, 1996.). Uzimanje aspekata posla u odnosu na radne vrijednosti također nudi određene prednosti: zbog svoje modularnosti i prilagodljivosti može poslužiti u svim situacijama odabira, od odabira škole, fakulteta, zanimanja ili pak konkretnoga posla unutar zanimanja, dok su mjere vrijednosti najčešće vezane uz radno okruženje.

Računalni sustavi za profesionalno savjetovanje poštuju navedene teorijske i empirijske spoznaje o dosezima kongruencije $u$ predviđanju pozitivnih profesionalnih ishoda. Zato neki kombiniraju kongruenciju izračunanu na osnovi interesa, vrijednosti i sposobnosti u jedinstven model, poput $O{ }^{*} \mathrm{Neta}$ ili Discovera. Drugi kongruenciju temelje na eklektički odabranim aspektima posla, poput $M B C D$-a, Vodiča kroz zanimanja ili Izbora zanimanja. Neki pak ostaju unutar jednoga teorijskog pristupa i kongruenciju zasnivaju na, primjerice, Hollandovoj tipologiji interesa, poput Slikovno-opisnog upitnika interesa, 
ili na vrijednostima, poput SIGI-ja. Odabir modela uparivanja osobina pojedinca i osobina radne okoline ovisi o teorijskoj usmjerenosti autora sustava, potrebi potencijalnih klijenata te općem cilju i svrsi računalnoga savjetovanja, odnosno računalno potpomognutoga profesionalnog usmjeravanja.

\section{ON-LINE SUSTAVI I ALATI ZA PROFESIONALNO SAVJETOVANJE}

U ovom pregledu računalnih sustava za profesionalno savjetovanje opisat ćemo ih samo nekoliko. Izbor među mnogim računalnim sustavima koji su trenutačno dostupni na mrežnim stranicama nije lak. Ipak, na osnovi dugovječnosti u savjetodavnoj praksi, teorijskoj utemeljenosti, broju evaluacijskih studija, dostupnosti na internetu te broju njihovih korisnika odabrano je njih sedam. Od međunarodnih sustava odabrali smo Discover, SIGI (Sistem for Interactive Guidance Information) $O{ }^{*}$ Net (The Occupational Information Network) te MBCD (Making Better Career Decision) jer su to sustavi koji se najčešće rabe i koji su i najzastupljeniji u stručnoj literaturi. Od domaćih sustava opisat ćemo Vodič kroz zanimanja, prvi on-line savjetodavni sustav razvijen na Odsjeku za psihologiju Filozofskog fakulteta u Zagrebu, te Izbor zanimanja i Slikovno-opisni upitnik interesa, alate razvijene nešto kasnije u Društvu za istraživanje i razvoj ljudskih potencijala Razbor. U Hrvatskoj postoji i sustav Moj izbor, izvorno razvijen u Velikoj Britaniji, a potom adaptiran i primijenjen u Hrvatskom zavodu za zapošljavanje. Međutim, za razliku od prethodno spomenutih on-line sustava i alata, to je software koji se trenutačno rabi samo u uredima Hrvatskoga zavoda za zapošljavanje i u malom broju osnovnih i srednjih škola koje su kupile licencu za njegovu upotrebu. Kako i kod nas računalno potpomognuto profesionalno savjetovanje danas postaje nezaobilaznim dijelom savjetodavnoga pristupa te kako važnost i dostupnost on-line tehnologije svakodnevno raste, valja očekivati da će ubuduće biti sve više takvih sustava i alata dostupnih na internetu.

\section{Discover (http://www.act.org/discover)}

Discover je jedan od pionirskih sustava za računalno potpomognuto savjetovanje, prvotno razvijen 1960-ih godina i sustavno razvijan do danas. Trenutačno program Discover postoji u dvjema verzijama - na internetu i na CD-u - te u dvjema inačicama - za osnovnoškolce te srednjoškolce i starije. Internetska inačica Discovera sastoji se od nekoliko modula. U početnom modulu korisnik planira način upotrebe programa, dostupne su mu obavijesti o programu te upute za uporabu. U sljedećem modulu klijent upoznaje svoje osobine i preferencije preko upitnika profesionalnih interesa, sposobnosti i radnih vrijednosti. Kada korisnik ispuni upitnike, sustav obrađu- 
DRUŠ. ISTRAŽ. ZAGREB GOD. 21 (2012), BR. 4 (118),

STR. 863-883

BABAROVIĆ, T. ŠVERKO, I.: TEORIJSKO je rezultate, izvještava korisnika o njima te prikazuje profesionalne opcije koje korisniku odgovaraju. U idućem se modulu korisnik može informirati o svijetu rada, osobinama zanimanja, obrazovnim profilima, fakultetima, odnosno srednjim školama. Postoji i modul za pomoć u natjecanju za posao, koji nudi korisniku pomoć u pisanju životopisa, molbe za posao, predstavljanja na intervjuu i sl. Zadnji modul odnosi se na mogućnost pregleda svih rezultata: od rezultata na upitnicima profesionalnih preferencija, preko popisa odabranih zanimanja, pa do uvida u način upotrebe sustava.

Jedna od ključnih osobina ovoga programskog sustava jest uparivanje osobina korisnika i osobina svijeta rada, odnosno pružanje savjeta o odgovarajućim zanimanjima na osnovi ispitanikovih preferencija i sposobnosti. Uparivanje se zasniva na Hollandovoj teoriji izbora zanimanja i na Predigerovim dimenzijama (Prediger, 1982.), koje leže u pozadini Hollandovih tipova. U novijim verzijama, od 1994. godine (Prediger i Staples, 1996.), mjera osobina ispitanika promijenila se iz mjere interesa $\mathrm{u}$ mjeru "preferencija osobina zanimanja" (eng. Occupation Attribute Preferences). Konkretan upitnik kojim se mjere preferencije ispitanika zove se Upitnik radnih preferencija (eng. Inventory of Work Preferences), a čestice obuhvaćene upitnikom mjere interese, radne vrijednosti, radne uvjete i neke konkretne osobine zanimanja. Dakle, Discover je proširio svoj koncepcijski okvir s mjera interesa na mjere aspekata posla, koje su po svojem obuhvatu nešto šire i izlaze iz strogog okvira Hollandove teorije.

\section{SIGI (http://www.sigi3.org)}

SIGI (System of Interactive Guidance and Information) također datira s kraja 60-ih godina 20. stoljeća te je prošao kroz razne evaluacijske i razvojne faze (npr. Norris i Shatkin, 1986.; Reardon i sur., 1988.). Njegova najnovija internetska inačica, SIGI3, podijeljen je u devet sesija ili modula. Počinje uvodnim modulom, koji upućuje korisnika kako se služiti sustavom, daje pregled sustava te preporučuje korisniku specifičan način upotrebe koji odgovara njegovim potrebama. Nakon uvodnoga, slijedi modul za utvrđivanje profesionalnih osobina korisnika, u kojem klijenti procjenjuju svoje radne vrijednosti, interese i neke od vještina. Slijedi modul pretraživanja, u kojem korisnik uz pomoć računala kreira personaliziranu listu preferiranih zanimanja. Unutar ovoga modula korisniku je omogućeno i da eliminira iz pretrage sva zanimanja za koja misli da mu ne odgovaraju. U SIGI-ju se uparivanje preferencija klijenata i osobina zanimanja i odabir najprihvatljivijih zanimanja zasniva na radnim vrijednostima (Katz, 1993.). U informacijskom modulu, koji slijedi, korisnik može dobiti informa- 
DRUŠ. ISTRAŽ. ZAGREB GOD. 21 (2012), BR. 4 (118),

STR. 863-883

BABAROVIĆ, T. ŚVERKO, I.: TEORIJSKO.

rovi zanimanja po njihovim osobinama. U sljedećem modulu korisnici dobivaju informacije o zahtjevima zanimanja, odnosno vještinama i sposobnostima koje su potrebne za pojedino zanimanje, a kroz interakciju s računalom korisnici utvrđuju posjeduju li oni potrebne vještine i sposobnosti za željena zanimanja. U modulu pripreme korisnik dobiva informacije o načinima školovanja za željeno zanimanje, kao i o konkretnim programima obrazovanja koji su korisniku dostupni. Isto tako, korisnik procjenjuje koliko mu je vremena i sredstava potrebno da završi pojedini oblik školovanja ili profesionalnog usavršavanja. Modul koji slijedi odnosi se na pomoć u postizanju obrazovnih i profesionalnih ciljeva. Ovdje korisnik može dobiti niz praktičnih informacija koje bi mu mogle pomoći; na primjer, kako pronaći novac za školovanje, koje su mogućnosti stipendiranja ili kreditiranja, kako rasporediti vrijeme ako se školuje uz rad ili kako se prilagoditi novoj obrazovnoj ili poslovnoj sredini. Predzadnji modul odnosi se na donošenje odluka, u kojem korisnik uz pomoć računala procjenjuje nekoliko profesionalnih opcija. Može se uspoređivati po tri profesionalne opcije (zanimanja) istodobno, i to tako da se važu potencijalni dobici (zadovoljenje preferencija) i zahtjevi zanimanja. Posljednji modul odnosi se na definiranje konkretnih koraka kako ostvariti profesionalni plan, odnosno kako ostvariti profesionalnu odluku donesenu u prethodnom koraku. Ovim modulom sustav pomaže korisniku da odredi konkretne kratkoročne ciljeve $u$ ostvarenju svojega profesionalnog plana, poput definiranja kada i gdje se školovati ili kako razviti nove vještine, odnosno kako se uspješno natjecati za posao.

\section{O*Net (http://www.onetonline.org/)}

O*NET (The Occupational Information Network) sveobuhvatan je sustav Američkoga zavoda za zapošljavanje, koji korisniku nudi informacije o svijetu rada i alate za planiranje karijere. Sustav je utemeljen na konceptu kongruencije i sadrži bazu podataka o zanimanjima koja objedinjuje ažurirane informacije o stotinama zanimanja (trenutačno je uključeno više od 800 zanimanja, a baza se stalno dopunjuje). Sva su zanimanja detaljno opisana unutar šest domena, koje predstavljaju jedinstven teorijski i empirijski utemeljen $O^{*}$ Netov model svijeta rada. Model uključuje tri domene vezane uz poželjne osobine radnika: poželjne osobine (sposobnosti, interese, radne vrijednosti i radne stilove), kompetencije (vještine, znanja, obrazovanje, stečene kvalifikacije) i radno iskustvo radnika (specifične treninge i edukacije, specifične vještine), te tri domene vezane uz obilježja zanimanja: opća obilježja zanimanja (radne aktivnosti te organizacijsko i radno okruženje), specifične informacije o poslu (konkretni radni zadaci te upotrijebljeni a- 
DRUŠ. ISTRAŽ. ZAGREB GOD. 21 (2012), BR. 4 (118)

STR. 863-883

BABAROVIĆ, T., ŠVERKO, I.: TEORIJSKO lati i tehnologije), kao i stanje na tržištu rada (trenutačno stanje i projekcije budućega zapošljavanja na tom području). Sva zanimanja procijenjena su i opisana nizom varijabli definiranih modelom. Prve procjene zanimanja dali su eksperti, ali se baza godišnje ažurira i dopunjuje procjenama zaposlenika u konkretnim zanimanjima. Cjelokupna $\mathrm{O}^{*} \mathrm{Net}$ baza podataka o zanimanjima, kao i popratni alati za pretraživanje i planiranje karijere, dostupni su javnosti bez naknade.

Savjetodavni modul $O^{*}$ Net sustava uključuje alate za profesionalno savjetovanje - test sposobnosti (Ability Profiler), upitnik profesionalnih interesa (Interest Profiler) te upitnik radnih vrijednosti (Work Importance Profiler). Sva zanimanja u bazi procijenjena su na svim spomenutim dimenzijama - zahtjevima posla vezanima uz sposobnosti, vrijednosnim dimenzijama i RIASEC tipovima radnih okolina. Zato se na temelju bilo kojeg upitnika može procijeniti kongruencija osobina pojedinca i zanimanja iz baze i korisniku ponuditi popis odgovarajućih zanimanja. Ipak, iako test sposobnosti i upitnik radnih vrijednosti imaju mogućnost računalnoga bodovanja odgovora, jedino je upitnik interesa u cijelosti adaptiran i prilagođen za on-line upotrebu i savjetovanje. On-line verziji upitnika interesa može se pristupiti preko adrese http://www. mynextmove.org/, koja je sastavni dio $O^{*}$ Net sustava. Nakon ispunjavanja upitnika, računalo ispitaniku grafički i numerički prikazuje rezultat na RIASEC tipovima interesa, uz kratke opise njihova značenja. U idućem koraku korisnik određuje željenu razinu obrazovanja, na temelju čega računalo formira konačan popis zanimanja koja odgovaraju ispitanikovim interesima i profesionalnim aspiracijama. Ponuđeni popis zanimanja povezan je s opisima u $O^{*} \mathrm{Net}$ bazi, pa se ispitanik može informirati o zanimanjima ako "klikne" na njih. Ova računalna verzija upitnika interesa pokazala se pouzdanom i valjanom mjerom Hollandovih tipova (Rounds i sur., 1999.). Pretpostavlja se da je samo pitanje vremena kada će i test sposobnosti i upitnik vrijednosti dobiti svoje on-line inačice i time obogatiti ovaj kompleksni računalni savjetodavni sustav.

\section{MBCD (http://mbcd.intocareers.org)}

MBCD ili Making Better Career Decision (Gati, 1996.) počeo se razvijati 1990-ih godina suradnjom istraživačkoga tima Židovskoga sveučilišta u Jeruzalemu (Hebrew University of Jerusalem) i Sveučilišta u Oregonu (University of Oregon). Svoju je internetsku inačicu dobio na početku 21. stoljeća (Gati i sur., 2003.), pa je time poprimio sve odlike računalnih sustava za profesionalno savjetovanje pete generacije (Carson i Cartwright, 1997.): dostupan je na WWW-u, uključuje veliku bazu informacija o zanimanjima i obrazovnim mogućnostima, a pruža i izravnu pomoć u donošenju profesionalnih odluka. 
DRUŠ. ISTRAŽ. ZAGREB GOD. 21 (2012), BR. 4 (118),

STR. 863-883

BABAROVIĆ, T. ŠVERKO, I.: TEORIJSKO.
Osnova $M B C D$ sustava jest trorazinski PIC model donošenja profesionalnih odluka kroz koji korisnik prolazi uz pomoć računala. Prva faza modela nazvana je prosijavanje (Pre-screening), a cilj joj je iz velikoga broja zanimanja odabrati manji broj obećavajućih opcija koje odgovaraju korisnikovim željama (Gati i sur., 2001.). Ta obećavajuća zanimanja trebalo bi detaljnije proučiti u drugoj fazi dubinskog istraživanja (In-depth exploration) i tako prikupiti što više informacija o svakoj od ponuđenih profesionalnih opcija te istražiti odgovaraju li osobine i zahtjevi zanimanja osobnim preferencijama i sposobnostima klijenta. Na osnovi takve analize neka se zanimanja odbacuju kao neodgovarajuća, pa ih ostaje samo nekoliko. Završna faza je odabir (Choice), u kojoj se odabire najbolja opcija, dok se odgovarajuća preostala zanimanja rangiraju prema preferencijama, počevši od onoga koje klijentu najviše odgovara, pa prema lošijim odabirima.

Sustav se koristi aspektima posla kojima operacionalizira ispitanikove preferencije i osobine zanimanja (Gati i sur., 1998.; Gati, 1998.). Aspekti sadrže radne vrijednosti, šira područja interesa, preferencije za iskorištavanje određenih sposobnosti te radne uvjete. Internetska verzija $M B C D$ sadrži 28 takvih aspekata posla za opis radnih preferencija. Uz pomoć istih aspekata posla procijenjena su i opisana zanimanja pohranjena u bazi sustava, što omogućuje izravnu usporedbu preferencija klijenta i osobina zanimanja. Tijekom faze prosijavanja korisnik odgovara na pitanja o preferencijama pojedinih aspekata posla, a posljedice svakoga svojeg odgovora može izravno vidjeti prateći kako se skraćuje popis odgovarajućih zanimanja nakon svake iskazane profesionalne preferencije. Nakon završene faze prosijavanja, sustav korisniku predočuje popis odgovarajućih zanimanja, koji klijent proučava u fazi dubinskog istraživanja. Za svako zanimanje korisnik može vidjeti podrobne opise radnih zadataka, nužne vještine i načine obrazovanja te tako ustanoviti u kojoj mjeri ponuđena zanimanja odgovaraju njegovim preferencijama. U trećoj fazi odabira klijentu je omogućeno da usporedi parove zanimanja, odnosno utvrdi koje bi zanimanje najbolje odgovaralo njegovim preferencijama (Gati i sur., 2003.).

\section{Vodič kroz zanimanja (http://mrav.ffzg.hr/zanimanja)}

Vodič kroz zanimanja prvi je hrvatski računalni sustav za profesionalno savjetovanje i dostupan je na internetu od 1999. godine. Razvijen je pri Katedri za psihologiju rada i ergonomiju Odsjeka za psihologiju Filozofskog fakulteta u Zagrebu pod vodstvom B. Šverka. Razvoj Vodiča financijski je potpomogao Institut Otvoreno društvo - Hrvatska, a njegovu evaluaciju Hrvatski zavod za zapošljavanje. Vodič je cjelovit računalni sustav za profesionalno savjetovanje koji korisniku nudi pomoć 
DRUŠ. ISTRAŽ. ZAGREB GOD. 21 (2012), BR. 4 (118)

STR. 863-883

BABAROVIĆ, T., ŠVERKO, I.: TEORIJSKOO.. pri donošenju profesionalnih odluka na temelju samoprocjene vještina, sposobnosti i preferencija, sveobuhvatne opise zanimanja i potrebnoga školovanja te korisne informacije o usmjeravanju karijere i natjecanju za posao.

Računalni sustav Vodiča organiziran je u pet modula. Prvi je modul početak, koji nudi opće informacije o sustavu i njegovim autorima. U drugom modulu, nazvanom karijera, korisniku je ponuđeno niz informacija o planiranju karijere i donošenju profesionalnih odluka. Klijent se upoznaje s pojmovima interesa, radnih vrijednosti i sposobnosti te njihovoj ulozi u izboru zanimanja. Pružaju mu se i informacije kako tražiti posao te upute kako se predstaviti poslodavcu molbom, životopisom i poslovnim intervjuom. Sljedeći modul, zanimanja, sadrži opise 248 najčešćih zanimanja u Hrvatskoj. Zanimanja i njihovi opisi preuzeti su iz tiskane verzije Vodiča kroz zanimanja (B. Šverko, 1998.). Navedeni su opisi poslova, radni uvjeti, poželjne osobine, način osposobljavanja te perspektive zapošljavanja. Zanimanja su svrstana u 37 većih "porodica", čime je korisniku pretraživanje zanimanja olakšano. Modul upitnik čini "srce" ovoga interaktivnog sustava. Radi se o samoprimjenjivom interaktivnom upitniku uz pomoć kojega računalo na osnovi korisnikovih odgovora pruža savjet korisniku o odgovarajućim zanimanjima. Upitnikom se utvrđuju korisnikove sposobnosti, vještine, radne preferencije, neke radne vrijednosti te interesi unutar Hollandovih tipova. Na osnovi odgovora u upitniku sustav korisniku pruža profesionalni savjet $\mathrm{u}$ obliku kraćega popisa zanimanja koja odgovaraju njegovim preferencijama. Na kraju modula korisnik je upućen da detaljnije prouči ponuđena zanimanja, odnosno pogleda njihove detaljne opise. Zadnji je modul indeks, odnosno abecedni popis zanimanja koji olakšava njihovo pretraživanje u bazi sustava.

Koncept kongruencije utemeljen je na aspektima posla. U Vodiču je 33 aspekta posla koja se mogu klasificirati u četiri šire kategorije: mentalne (intelektualne) aktivnosti, senzomotorni zahtjevi, radni uvjeti i Hollandovi tipovi interesa. Bazu zanimanja čini 248 zanimanja procijenjenih na navedenim aspektima, a uparivanje odgovora klijenta i osobina zanimanja izvodi se preko svih aspekata. Najprikladnija zanimanja za klijenta odabiru se na temelju matematičkih algoritama i takav popis u pravilu sadrži od pet do devet odgovarajućih zanimanja za svakoga klijenta.

Opsežna validacijska studija potvrdila je opravdanost primjene Vodiča kroz zanimanja u profesionalnom usmjeravanju. Potvrđena je dobra pouzdanost i dobra valjanost procjena zanimanja u bazi te ispitanikovih odgovora na upitniku. Utvrđena je logična struktura aspekata posla, očekivane razlike $u$ 
DRUŠ. ISTRAŽ. ZAGREB GOD. 21 (2012),

BR. 4 (118),

STR. 863-883

BABAROVIĆ, T., ŚVERKO, I.:

TEORIJSKO. profesionalnim preferencijama s obzirom na spol i trenutačno profesionalno usmjerenje korisnika. Uočena je i visoka sličnost profesionalnih savjeta koje daje Vodič sa savjetima dobivenim kod profesionalnih savjetovatelja u Zavodu za zapošljavanje te sa savjetima na Hollandovom upitniku interesa, kao i visoko zadovoljstvo klijenata savjetom iz Vodiča (B. Šverko i sur., 2002.).

\section{Izbor zanimanja (http://www.karijera.hr)}

Izbor zanimanja je on-line računalni alat za profesionalno savjetovanje namijenjen pomoći grupama pojedinaca koji su u procesu donošenja odluka o karijeri. Razvijen je 2007. godine u Društvu za istraživanje i razvoj ljudskih potencijala Razbor, kada je i validiran i postavljen na internetsku stranicu http://www. karijera.hr. Namijenjen je učenicima završnih razreda osnovne i srednje škole, studentima koji biraju specijalizaciju te odraslim osobama koje su u tranzicijskom razdoblju svoje karijere. Za razliku od dosad opisanih sustava, Izbor zanimanja ima samo savjetodavni modul, a ne sadrži bazu opisa zanimanja. Njegovu bit čini opsežan instrument za samoprocjenu vlastitih preferencija i sposobnosti, na temelju kojega klijenti dobivaju informaciju o za njih prikladnim zanimanjima.

Kongruencija se i u ovom savjetodavnom sustavu temelji na pristupu aspektima posla. Autori su odabrali 31 aspekt posla koji su smatrali ključnim za opis raznovrsnih zanimanja zastupljenih u svijetu rada (npr. rad sa strankama, odgovornost u radu, raznolikost, plaća, stupanj obrazovanja), pa su isti aspekti posla uzeti i za procjenu radnih okolina i za procjenu osobina klijenata. Ukupno 120 zanimanja procijenili su nezavisni procjenjivači na svim spomenutim aspektima posla, pa je tako formirana baza zanimanja. Zatim je konstruiran upitnik profesionalnih preferencija za klijente, koji se sastoji od dva dijela - procjene sviđanja pojedinih aspekata posla i procjene važnosti pojedinih aspekata prilikom donošenja odluke o karijeri. Uparivanje odgovora klijenata s osobinama zanimanja iz baze odvija se na temelju odabranih algoritama, na temelju čega se formira popis zanimanja, odnosno predloženih profesionalnih opcija.

Na temelju detaljne analize ovog alata za profesionalno savjetovanje potvrđena je njegova valjanost (Babarović, 2009.). Ustanovljeno je da su zanimanja u bazi odgovarajuće procijenjena, jer su procjene raznih procjenjivača homogene i odražavaju očekivanu strukturu aspekata (Babarović i I. Šverko, 2010.a). Na uzorcima srednjoškolaca, studenata i zaposlenih utvrđeno je da i procjene klijenata također imaju logičnu strukturu te da dobiveni savjeti odgovaraju profesionalnom usmjerenju klijenata i slijede očekivane rodne obrasce. Profesio- 
nalni savjeti koje generira Izbor zanimanja korespondentni su s onima utemeljenima na otprije validiranom upitniku interesa, a klijenti smatraju kako dani savjeti odgovaraju njihovim profesionalnim preferencijama (Babarović, 2009.).

\section{Slikovno-opisni upitnik interesa (http://www.karijera.hr)}

Slikovno-opisni upitnik interesa još je jedan od hrvatskih internetskih alata za profesionalno savjetovanje utemeljenih na konceptu kongruencije. I ovaj je alat osmišljen u Društvu za istraživanje i razvoj ljudskih potencijala Razbor i objavljen na web-stranici http://www.karijera.hr 2009. godine uz financijsku pomoć Gradskog ureda za obrazovanje, kulturu i šport Grada Zagreba. Namijenjen je u prvom redu mlađim klijentima, no prikladan je i za odrasle. Za razliku od dosad opisanih sustava i alata koji na temelju kongruencije korisnicima daju povratnu informaciju o, za njih, prikladnim zanimanjima, ovaj samospoznajni alat korisnicima omogućuje da bolje upoznaju svoje profesionalne interese, što je jedan od ključnih elemenata usmjeravanja karijere.

Slikovno-opisni upitnik interesa temelji se na Hollandovoj teoriji i profesionalne interese operacionalizira RIASEC modelom. Sastoji se od 48 zanimanja opisanih nazivom, najvažnijim radnim aktivnostima te fotografijom osobe koja obavlja posao u tom zanimanju. Za svako zanimanje korisnici trebaju procijeniti koliko im se sviđa i koliko bi u njemu bili uspješni. Na temelju njihovih odgovora formiraju se rezultati na šest tipova interesa - realistički, istraživački, umjetnički, socijalni, poduzetnički i konvencionalni. Izraženost pojedinih interesa svakom se korisniku prikazuje u obliku histograma, pa klijent može lako vidjeti koji su interesi izraženiji u njegovu profilu. Klikom na svaki stupac histograma otvara se opis toga tipa interesa, zajedno s popisom zanimanja karakterističnim za svaki tip. Ovaj alat omogućuje klijentima i da rezultate pošalju na svoju e-mail adresu kako bi im se kasnije mogli vratiti.

Validacija ovoga sustava provedena na uzorcima osnovnoškolaca, srednjoškolaca, studenata, zaposlenih i nezaposlenih osoba pokazala je kako se Slikovno-opisni upitnik interesa može rabiti kao alat za profesionalno usmjeravanje. RIASEC skale potvrdile su svoju heksagonalnu strukturu, koja u funkciji dobi postaje sve bliža teorijskom modelu (I. Šverko i sur., 2012.). Potvrđeni su očekivani odnosi RIASEC tipova i osobina ličnosti te visoke povezanosti s drugim RIASEC mjerama interesa (I. Šverko i Babarović, 2011.). Nadalje, opažene su očekivane i logične razlike $u$ interesima muškaraca i žena, osoba različitih profesionalnih usmjerenja, a klijenti svih dobnih skupina izrazili su zadovoljstvo dobivenim profesionalnim savjetom (Babarović i I. Šverko, 2010.b). 
U zadnjih desetak godina računalni sustavi za profesionalno savjetovanje postali su vrlo uobičajeni savjetodavni alati. Korisnici vole njihovu samoprimjenjivost, brzinu kojom pružanju profesionalne savjete te lakoću kojom uz njihovu pomoć mogu pretraživati zanimanja i svijet rada. Razvoj informacijske tehnologije danas omogućuje laku i financijski dostupnu izvedbu takvih sustava, pa zbog toga u zadnje vrijeme svjedočimo brzom povećanju njihova broja na internetu. Upravo je zbog toga važno inzistirati na teorijskom utemeljenju računalnih sustava za profesionalno savjetovanje, odnosno na transparentnim opisima primijenjenih modela donošenja profesionalnih odluka te na jasnim empirijskim dokazima njihove valjanosti.

\section{LITERATURA}

Assouline, M. i Meir, E. I. (1987). Meta-analysis of the relationship between congruence and well-being measures. Journal of Vocational Behavior (Special Issue: Conceptual and Methodological Issues in Person/ Environment Fit Research), 31(3), 319-332. doi:10.1016/0001-8791(87) 90046-7

Babarović, T. (2009). Računalno potpomognuto profesionalno savjetovanje: usporedba različitih modela donošenja odluka. Doktorska disertacija. Zagreb: Filozofski fakultet.

Babarović, T. i Šverko, I. (2010a). La relazione tra le diverse caratteristiche degli aspetti professionali: il livello tipico, la varianza e gli aspetti chiave (Relation between different measures of career-related aspects: Typical level of aspects, within-occupational aspects variance, and core aspects). U L. Nota i S. Soresi (Ur.), Sfide e nuovi orizzonti per l'orientamento: Metodologie e buone prectiche (str. 207-215). Firenze, Italia: Giunti Organizzazioni Speciali.

Babarović, T. i Šverko, I. (2010b). Slikovno-opisni upitnik interesa: preliminarna provjera na studentskom uzorku. XVII. Dani psihologije u Zadru. Odjel za psihologiju, Sveučilište u Zadru, Zadar.

Carson, A. D. (2000). A history of computer-assisted career guidance systems. Posjećeno 5. 7. 2008. na: http://vocationalpsychology.com/essay 8CACGSs.htm

Carson, A. D. (2002). Dictionary of vocational psychology. Posjećeno 5. 7. 2008. na: http://vocationalpsychology.com

Carson, A. D. i Cartwright, G. (1997). Fifth-generation computer-assisted career guidance systems. Career Planning and Adult Development Journal, 13(1), 19-40.

Chartrand, J. i Walsh, W. B. (1999). What should we expect from congruence. Journal of Vocational Behavior, 55(1), 136-146. doi:10.1006/ jvbe.1999.1703

Dawis, R. V. (1990). Vocational interests, values, and preferences. U M. D. Dunnette i L. M. Hough (Ur.), Handbook of industrial and organizational psychology: Vol. 2 (2nd ed., str. 833-871). Palo Alto, CA: Consulting Psychologists Press. 
DRUŠ. ISTRAŽ. ZAGREB GOD. 21 (2012) BR. 4 (118),

STR. 863-883

BABAROVIĆ, T., ŠVERKO, I.: TEORIJSKO
Dawis, R. V. (1996). The theory of work adjustment and person-environment-correspondence counseling. U D. Brown, L. Brooks i sur. (Ur.), Career choice and development: Applying contemporary theories to practice (3rd ed., str. 75-120). San Francisco: Jossey-Bass Publishers.

Dawis, R. V. i Lofquist, L. H. (1984). A psychological theory of work adjustment. Minneapolis: University of Minnesota Press.

Dawis, R. V., England, G. W. i Lofquist, L. H. (1964). A theory of work adjustment. Minnesota Studies in Vocational Rehabilitation (br. 15, str. 1-27). Minneapolis: Industrial Relation Center.

Dawis, R. V., Lofquist, L. H. i Weiss, D. J. (1968). A theory of work adjustment (a revision). Minnesota Studies in Vocational Rehabilitation, 23, 1-13.

Fritzsche, B. A. i Parrish, T. J. (2005). Theories and research on job satisfaction. U S. D. Brown i R. W. Lent (Ur.), Career development and counseling: Putting theory and research to work (str. 180-202). Hoboken, NJ: Wiley.

Gati, I. (1994). Computer-assisted career counseling: Dilemmas, problems and possible solutions. Journal of Counseling and Development, 73(1), 51-56. doi:10.1002/j.1556-6676.1994.tb01709.x

Gati, I. (1996). Computer-assisted career counseling: Challenges and prospects. U M. L. Sawicas i W. B. Walsh (Ur.), Handbook of career counseling theory and practice (str. 169-190). Davies-Black Publishing, CA: Palo Alto.

Gati, I. (1998). Using career-related aspects to elicit preferences and characterize occupations for better person-environment fit. Journal of Vocational Behavior, 52(3), 343-356. doi:10.1006/jvbe.1997.1623

Gati, I. i Asher, I. (2001). The PIC model for career decision making: Pre-screening, in-depth exploration, and choice. U F. T. L. Leong i A. Barak (Ur.), Contemporary models in vocational psychology (str. 7-51). Mahwah, NJ: Erlbaum.

Gati, I., Fassa, N. i Mayer, Y. (1998). An aspect-based approach to person-environment fit: A comparison between the aspect structure derived from characteristics of occupations and that derived from counselees' preferences. Journal of Vocational Behavior, 53, 28-43.

Gati, I., Garty, Y. i Fassa, N. (1996). Using career-related aspects to assess person-environment fit. Journal of Counseling Psychology, 63, 196-206.

Gati, I., Saka, N. i Krausz, M. (2001). Should I use a computer-assisted career guidance system? It depends on where your career decision-making difficulties lie. British Journal of Guidance $\mathcal{E}$ Counselling, 29(3), 301-321. doi:10.1080/03069880124945

Gati, I., Kleiman, T., Saka, N. i Zakai, A. (2003). Perceived benefits of using an Internet-based interactive career planning system. Journal of Vocational Behavior, 62(2), 272-286. doi:10.1016/S0001-8791(02)00049-0 Gottfredson, G. D. i Holland, J. L. (1989). Dictionary of Holland occupational codes. Odessa, FL: Psychological Assessment Resources.

Harmon, L. W., Hansen, J. C., Borgen, F. H. i Hammer, A. L. (1994). Strong interest inventory: Applications and technical guide. Palo Alto, CA: Consulting Psychologists Press, Inc. 
DRUŠ. ISTRAŽ. ZAGREB GOD. 21 (2012), BR. 4 (118)

STR. 863-883

BABAROVIĆ, T. ŚVERKO, I.: TEORIJSKO.
Holland, J. L. (1959). A theory of vocational choice. Journal of Counseling Psychology, 6(1), 34-45. Reprint u H. J. Peters i J. C. Hansen (Ur.) (1966). Vocational guidance and career development. New York: The Macmillan Company. doi:10.1037/h0040767

Holland, J. L. (1976). Vocational preferences. U D. M. Dunette (Ur.), Handbook of industrial and organizational psychology (str. 521-570). Chicago: Rand McNally College Publishing Company.

Holland, J. L. (1985). Vocational preference inventory (VPI): 1985 Edition. Psychological Assessment Resources.

Holland, J. L. (1994). Self-directed search: Assessment booklet, A guide to educational and career planning. Odessa: Psychological Assessment Resources, Inc.

Holland, J. L. (1997). Making vocational choices: A theory of vocational personalities and work environments. Odessa: Psychological Assessment Resources, Inc.

Iaccarino, G. (2001). Computer assisted career-guidance systems. U D. A. Luzzo (Ur.), Career counseling of college students (str. 173-189). Washington, DC: American Psychological Association Press.

Katz, M. R. (1993). Computer-assisted career decision making: The guide in the machine. Hillsdale, NJ: Lawrence Erlbaum Associates.

Norris, L. i Shatkin, L. (1986). SIGI plus at ETS: Development and field testing (Research Memorandum). Educational Testing Service, Princeton, NJ.

Oliver, L. W. i Whiston, S. C. (2000). Internet carer assessment for the new millennium. Journal of Career Assessment, 8(4), 361-369. doi:10. 1177/106907270000800405

Parsons, F. (1909). Choosing a vocation. Boston: Houghton Miffin Company.

Prediger, D. J. (1982). Dimensions underlying Holland's hexagon: Missing link between interests and occupations? Journal of Vocational Behavior, 21(3), 259-287. doi:10.1016/0001-8791(82)90036-7

Prediger, D. J. (2000). Holland's hexagon is alive and well - though somewhat out of shape: Response to Tinsley. Journal of Vocational Behavior, 56(2), 197-204. doi:10.1006/jvbe.1999.1737

Prediger, D. J. i Staples, J. G. (1996). Linking occupational attribute preferences to occupations (ACT Research Report No. 96-3). Iowa City. IA: ACT, Inc.

Pryor, R. G. L. (1982). Values, preferences, work ethics, and orientation to work: Towards a conceptual and empirical integration. Journal of Vocational Behavior, 20(1), 40-52. doi:10.1016/0001-8791(82)90062-8

Rayman, J. R. (1990). Computers and career counseling. U W. B. Walsh i S. H. Osipow (Ur.), Career counseling: Contemporary topics in vocational psychology (str. 225-262). New Jersey: Lawrence Erlbaum Associates, Inc.

Reardon, R. C., Sampson, J. P., Jr., Ryan-Jones, R. E., Peterson, G. W. i Shahnasarian, M. (1988). A comparative analysis of the impact of two generations of a computer-assisted career guidance system - SIGI and SIGI PLUS (technical report No. 7). Tallahassee, FL: Florida State Univer- 
DRUŠ. ISTRAŽ. ZAGREB GOD. 21 (2012) BR. 4 (118),

STR. 863-883

BABAROVIĆ, T., ŠVERKO, I.: TEORIJSKO... sity, Center for the Study of Technology in Counseling and Career Development.

Reile, D. M. i Harris-Bowlsbey, J. (2000). Using the Internet in career planning and assessment. Journal of Career Assessment, 8(1), 69-84. doi:10. 1177/106907270000800106

Rounds, J. B., Dawis, R. V. i Lofquist, L. H. (1987). Measurement of person-environment fit and prediction of satisfaction in the theory of work adjustment. Journal of Vocational Behavior, 31(3), 297-318. doi:10.1016/0001-8791(87)90045-5

Rounds, J., Mazzeo, S. E., Smith, T. J., Hubert, L., Lewis, P. i Rivkin, D. (1999). O*NET computerized interest profiler: Reliability, validity, and comparability. Raleigh, NC: National Center for O*NET Development. http://www.onetcenter.org/dl_files/IP_RVS.pdf

Sampson, J. P., Jr. (1994). Factors influencing the effective use of computer-assisted careers guidance: The North American experience. British Journal of Guidance \& Counseling, 22(1), 91-106. doi:10.1080/ 03069889408253668

Sampson, J. P., Jr. (1997, April). Helping clients get the most from computer-assisted career guidance systems. Paper presented at the Australian Association of Career Counsellors 7th National/International Conference, Brisbane. Posjećeno 3. 2. 2009. na: http://www.career. fsu.edu/techcenter/computer_applications/pc_based_models.html

Spokane, A. R. (1985). A review of research on congruence in Holland's theory of careers. (Monograph). Journal of Vocational Behavior, 26(3), 306-343. doi:10.1016/0001-8791(85)90009-0

Spokane, A. R., Meir, I. E. i Catalano, M. (2000). Person-environment congruence and Holland's theory: A review and reconsideration. Journal of Vocational Behavior, 57(2), 137-187. doi:10.1006/jvbe.2000. 1771

Šverko, B. (Ur.) (1998). Vodič kroz zanimanja. Zagreb: Razbor.

Šverko, B., Akik, N., Babarović, T., Brčina, A. i Šverko, I. (2002). Validity of E-advice: The evaluation of an Internet-based system for career planning. International Journal for Educational and Vocational Guidance, 2(3), 193-215. doi:10.1023/A:1020668118108

Šverko, I. i Babarović, T. (2006). The validity of Holland's theory in Croatia. Journal of Career Assessment, 14(4), 490-507. doi:10.1177/ 1069072706288940

Šverko, I. i Babarović, T. (2011). The equivalence of liking and competence interest measures: The appropriateness of their combined use in the assessment of RIASEC types. U S. Soresi (Ur.), Abstracts: Vocational designing and career counselling: Challenges and new horizons. Padova: Universita degli studi di Padua.

Šverko, I., Međugorac, V. i Babarović, T. (2012). Struktura profesionalnih interesa u funkciji dobi: evaluacija Slikovno-opisnog upitnika interesa. U Z. Penezić, V. Ćubela Adorić i sur. (Ur.), XVIII. Dani psihologije u Zadru. Odjel za psihologiju, Sveučilište u Zadru, Zadar.

Tinsley, H. E. A. (2000). The congruence myth: An analysis of the efficacy of the person-environment fit model. Journal of Vocational Behavior, 56(2), 147-179. doi:10.1006/jvbe.1999.1727 
DRUŠ. ISTRAŽ. ZAGREB GOD. 21 (2012), BR. 4 (118)

STR. 863-883

BABAROVIĆ, T. ŠVERKO, I.: TEORIJSKO.
Tracey, T. J. G. (2002). Personal Globe Inventory: Measurement of the spherical model of interest and competence beliefs [Monograph]. Journal of Vocational Behavior, 60(1), 113-172. doi:10.1006/jvbe.2001.1817 Tracey, T. J. G., Darcy, M. i Kovalski, T. (2000). A closer look at person-environment fit. Journal of Vocational Behavior, 56(2), 216-224. doi:10. 1006/jvbe.1999.1733

Tranberg, M., Slane, S. i Ekeberg, S. E. (1993). The relationship between interest congruence and satisfaction: A metaanalysis. Journal of Vocational Behavior, 42(3), 253-264. doi:10.1006/jvbe.1993.1018

Tsabari, O., Tziner, A. i Meir, E. I. (2005). Updated meta-analysis on the relationship between congruence and satisfaction. Journal of $\mathrm{Ca}$ reer Assessment, 13(2), 216-232. doi:10.1177/1069072704273165

\section{The Theoretical Background of Computer Assisted Career Guidance Systems}

Toni BABAROVIĆ, Iva ŠVERKO

Institute of Social Sciences Ivo Pilar, Zagreb

The paper examines modern computer-assisted career guidance systems, their main characteristics, as well as their theoretical foundation. First we describe the development of systems for computer-assisted career guidance, with the emphasis on the current generation of on-line counseling systems. Then the concept of congruence or person-environment fit is explained: the individuals who have chosen careers which are in accordance with their personal characteristics are more likely to be both satisfied with their jobs and successful at work. Although the concept of congruence is the main basis of theories of vocational choice and computer-assisted career guidance systems, the results of all important meta-analyses show a weak relationship between P-E congruence and job satisfaction. Possible explanations for this finding are identified and the aspect-based approach is presented as a possible solution. Finally, seven best-known on-line systems for vocational counseling are described: Discover, SIGI, O*Net, Making Better Career Decisions, Careers Guide, Career Choice and Pictorial and Descriptive Interest Inventory.

Keywords: computer-assisted career guidance systems, theories of vocational choice, congruence, aspect-based approach, internet 